\title{
Which is More Difficult? Losing Hair or Losing Breast: A Qualitative Study
}

\author{
Cemile Aktuğ $\breve{g}^{1}$, Ayla Gürsoy ${ }^{2}$ \\ ${ }^{1}$ Faculty of Health Sciences, Nursing Department, Gümüşhane University, Turkey. \\ ${ }^{2}$ Faculty of Health Sciences, Nursing Department, Antalya Bilim University, Turkey.
}

\section{Article Details \\ Article Type: Research Article \\ Received date: $14^{\text {th }}$ April, 2021 \\ Accepted date: $30^{\text {th }}$ June, 2021 \\ Published date: $02^{\text {nd }}$ July, 2021}

"Corresponding Author: Cemile Aktuğ, Faculty of Health Sciences, Nursing Department, Gümüşhane University, Turkey . E-mail: cemileaktug@gmail.com

Citation: Aktuğ, C., Gürsoy, A. (2021). Which is More Difficult? Losing Hair or Losing Breast? A Qualitative Study. J Comp Nurs Res Care 6(2):174. doi: https://doi.org/10.33790/jcnrc1100174.

Copyright: $(02021$, This is an open-access article distributed under the terms of the Creative Commons Attribution License 4.0, which permits unrestricted use, distribution, and reproduction in any medium, provided the original author and source are credited.

\begin{abstract}
The study was conducted to determine how women with breast cancer perceive chemotherapy-induced alopecia. This qualitative study included 20 patients with chemotherapy-induced alopecia. The data were collected through the semi-structured interview method and analyzed using the "phenomenological analysis" method. Perceptions and experiences of women with breast cancer about chemotherapy-induced alopecia were examined under six themes; facing alopecia, perceiving alopecia, hiding alopecia, changes in life after alopecia, keeping hope alive, and facilitating the difficulties experienced. When women lost their hair, they experienced sadness, anxiety, panic, and regret. Most women shaved their hair and used accessories such as wigs, bandanas, and headscarves to hide their hair loss and not to experience alopecia. The women who lost their hair worried that their spouses would not like them anymore and the majority preferred to hide their alopecia not to worry their children. Besides, they avoided entering social circles because alopecia made their disease visible. It was seen that those who knew that they would lose their hair, who believed that it was their destiny, and who had support systems accepted their situation more easily. The study results provide detailed information on how women perceived hair loss and will contribute to identifying nursing interventions that will help improve adaptability to alopecia and coping mechanisms.
\end{abstract}

Keywords: Alopecia, chemotherapy, breast cancer, breast care nursing, qualitative study

\section{Introduction}

Breast cancer, which is the most frequent cancer type among women in the world, is the second leading cause of cancer-related deaths [1]. According to the World Health Organization (WHO) data, breast cancer accounts for $24.5 \%$ of cancers in women, and 2.1 million people are diagnosed each year [2]. In our country, the incidence of breast cancer is 43.8 per hundred thousand [3]. It is also the most common cancer type in women, and 17,531 women are diagnosed with breast cancer every year [4,5].

Since it can lead to a wide variety of problems in patients, breast cancer treatment and care should be handled with multiple approaches. The most common form of treatment in breast cancer is surgery [6-9]. In addition to surgical treatment, adjuvant therapy is also employed for different purposes. In adjuvant therapy, chemotherapy, radiotherapy, and hormonal treatments are administered together depending on the stage of cancer [10]. The main principle of adjuvant chemotherapy is to eliminate the micrometastases that may occur after surgery and to stop the growth and recurrence of the tumor without damaging the healthy cells of the patient. Different antineoplastic agents are used in different combinations in chemotherapy [11].

Adjuvant chemotherapy has some negative impacts on the patient. Chemotherapy treatment prevents cancer cells from developing and multiplying and damages cancer cells but affects normal healthy cells too. The frequency and pattern of these side effects vary according to the chemotherapeutic type, the application method, and the individual characteristics of the patient [12-14].

The most common side effect that occurs on the skin due to chemotherapy is alopecia. Hair follicles are areas where blood circulation is intense. Therefore, any drug that enters the body quickly reaches the hair follicle through the circulation. If the drug taken moves to the root of the hair intensely for a long time, diffuse alopecia may occur by causing full hair loss [15]. Alopecia usually starts one to three weeks after the first dose of chemotherapy, and full alopecia occurs within one to two months [15-18].

The new appearance due to a hair loss transforms the person from a healthy individual to a cancer patient. Therefore, patients consider alopecia as one of the most severe and exhausting side effects of chemotherapy [19]. Although alopecia during treatment does not threaten life, it can negatively affect the physical appearance, body image, sexuality, and self-esteem of the patient [20]. Patients can perceive alopecia as visible evidence of their disease and treatment. It is a symbol of cancer for the patient and his environment, which causes weakness, loss of privacy, change in self-perception, and sexual attraction $[16,21]$. The change in body image caused by alopecia may negatively affect the compliance and coping strength of patients receiving chemotherapy. Alopecia, which can be considered unimportant, may have a shocking effect on the person due to the change in the body image $[22,23]$. Özgül et al., Mundstedt et al. reported that alopecia was the most traumatic side effect according to $47 \%$ of women, while $8 \%$ refused chemotherapy due to alopecia. Various studies determined that patients tried to hide alopecia by wearing wigs, headscarves, bandanas, or hats [24, 25].

There are many studies on the side effects of chemotherapy in the treatment of breast cancer [25-28] and the incidence of alopecia in the literature. Studies on the incidence of alopecia have also been conducted. However, how alopecia affects the emotional wellbeing of patients in our country has been infrequently reported. 
This research was carried out to determine how women with breast cancer perceive chemotherapy-induced alopecia.

\section{Materials and Methods}

In this phenomenological type of study, the criterion sampling method, one of the purposeful sampling methods, was used. The study group consisted of patients who had a mastectomy for primary breast cancer, who received chemotherapy for breast cancer for the first time and had alopecia associated with it. Exclusion criteria of the study were having psychiatric illnesses requiring treatment, having non-chemotherapy-induced alopecia, and having a deformity (amputation, scar, burn scar, etc.) or loss of function that may affect their body image. Patients who came for treatment or post-treatment control in a chemotherapy unit of a university hospital and met the sample criteria were included in the study.

Women who agreed to participate in the study were interviewed in a suitable room before receiving chemotherapy. Those who did not want to meet in the clinic were arranged an appointment by phone and were interviewed in a suitable room in their home where only the researcher and the interviewee were present.

In the collection of the data, a patient descriptive information form including the socio-demographic characteristics of the patients (age, marital and employment status, education level, diagnosis, duration of disease, the time between the onset of alopecia and the interview, the use of the scarf, wig and bandana and the date of the interview) and a semi-structured interview form consisting of eight open-ended questions and other related questions that further the subject to direct the participant to reflect on the details were used. The duration of the interviews varied between 15 and 40 minutes (average 25 minutes). The elapsed time after the diagnosis of breast cancer in women varied between 2 and 6 months. The period between the onset of alopecia after chemotherapy and the date of the interview varied between 15 days and 4 months.

\section{Evaluation of Data}

The phenomenological analysis method was used to analyze the data. The first transcriptions of all interviews with women were made by the researcher. At this stage, the voice recordings of the interviews were transcribed verbatim. The first data were carefully read until the researcher comprehended them well. Then, the notes written by two other researchers about the participant during the interview (the tone of the participant, the movements and facial expressions, etc.) were added and structured. After that, relevant data were categorized under specific groups by two researchers independently within the framework of interview software. Themes based on these categories were created. Then these themes were checked and finalized. At the last stage, women's perceptions of alopecia were interpreted and reported [29, 30].

\section{Ethical considerations}

Ethics committee permission was obtained from the Faculty of Medicine Clinical Research Ethics Committee of the university where the research was conducted, and the institution's permission was obtained from the medical faculty hospital. Besides, the women were informed about the purpose of the study, and the recording of the interviews and their written informed consent was obtained from those who agreed to participate.

\section{Results}

The mean age of the participants was $48.15 \pm 9.44$ (min.:33, max. $: 61$ ) and $65 \%$ of them had secondary or higher education levels. $90 \%$ of the participants were married and 50\% were working. Themes created a result of data analysis are shown in Figure 1.

\begin{tabular}{|ll|}
\hline Confronting alopecia \\
\hline$\bullet$ & Taking care of hair as much as health \\
\hline Perceiving alopecia \\
\hline Hiding alopecia \\
\hline$\bullet$ & Taking care of hair as much as health \\
\hline & Getting used to over time \\
\hline Changes in life after alopecia \\
\hline Being worried about her partner's feelings \\
Trying not to worry children \\
Not wanting to meet people outside the family \\
\hline
\end{tabular}

\section{Confronting Alopecia}

\section{Taking care of hair as much as health}

Half of the participants considered hair loss as a traumatic experience. Some of them stated that the loss was more upsetting than being cancer. Most of the participants with various negative emotions felt sorry for their hair loss and wanted to cry. Other than being upset, the emotions experienced by women the most were anxiety, panic, and regret.

- "When clumps of hair started to come out in my hands, (stopped, breathing deeply), I said 'God what am I going to do now?' I wanted to shout. I locked myself out of rooms and the bathroom. I cried. I wanted to cry loudly. I buried my head on the pillow and cried.... (cried). I used to be a very active and cheerful person. Now I feel like devastated"(20. Participant). 
For the other half of the participants, their health was more important than their hair loss. The important thing for them was to have a successful treatment and survive.

- "Personally it doesn't matter to me. I mean, it is only an image, my hair may not grow again. I don't care as long as the result is good. I just hope it because the falling out of my hair and eyebrows is somehow normal things" (5. Participant).

- "It's okay for me, I'm better. Let it fall out, I said to myself. At least, I don't have to collect hair from the ground anymore" (9. Participant).

Some of the participants had already known that they would lose their hair. However, they expressed that knowing something was different from experiencing it. They felt bad and even got depressed when their hair started to fall out. One of the participants was even more affected by the loss of her hair than the removal of her breast.

- "When I grabbed my hair like that this (showing).... Of course, I had been waiting for it, but for a moment you feel like you are scared. But waiting for something and experiencing it suddenly is completely different. I mean you tremble at that moment" (I. Participant).

Knowing that their hair would grow again enabled some participants to maintain their hopes and confront their hair loss more easily. Others did not care about their hair loss as they found other undesirable effects of chemotherapy much more difficult. Although alopecia was an important side effect for most of the participants, nausea was a symptom that was sometimes more troublesome than alopecia for the majority.

As a result of the hair loss, the participants described themselves as incomplete, half, ugly and male-like. Considering these definitions, it was seen that not only body image but also the self-esteem of women were negatively affected.

- “Well, I'm feeling useless now .... I feel bruised. I have no hair, no breast. And my periods will also stop because of the medication. As a result, I don't know...you set off on a path and you stop there. You can't go forward...but you don't want to go back either"(8. Participant).

Others' dissatisfaction with the change in their appearance was reflected in their style of clothing. They reflected this feeling as sloppy dressing, dislike whatever they were wearing and not taking care of their style.

- "But look at me... what's the use of dressing because I have no hair, no eyebrows? hah...(laughs). I am wearing whatever I find at home. I pay attention to wearing loose clothes (laughs)"(11. Participant).

\section{Hiding Alopecia}

Almost no participants wanted to encounter hair loss, so the majority of them cut their hair short or shaved before chemotherapy treatment. Some did so because they did not want to see their hair fall out, while others did not want it to fall on their bed. Participants who did not have their hair cut at the beginning were also very negatively affected, and they decided to have their hair cut with the onset of falling of the hair.

- "When my hair first started to fall out, they came to my hand, piece by piece, clumps of hair fell out, so I had my hair cut a male model. Not to be affected badly in case my hair would fall out suddenly, I had number 3 hair cut"(10. Participant).

The participants also reported that they preferred to cover their heads because some people made comments about them. Therefore, they felt a need to cover their heads with accessories such as berets, bandanas, and scarves and accessories, as alopecia made their diseases visible.

Almost half of the participants had already been covering their heads before their hair fell out, but those who did not started to do so as well. They chose to hide the absence of their hair in this way.

- "I normally covered my head near others anyway. Now I am wearing a beret or a scarf. Losing my hair hasn't affected me at all" (7. Participant.)

- $\quad$ "I am just covering my hair with colorful things. I mean I reflect my personality on my hair...I always used fancy things. I used beaded bandanas. I reflected my usual style to the bandana" (12. Participant).

\section{Changes in life after alopecia}

\section{Being worried about her partner's feelings}

The participants thought that their spouses did not like them anymore due to the change in their appearance. They did not want to be seen, so they restricted their relationship, and some of them did not even sleep in the same bed with their spouses. Although some of them stated that this situation did not affect their relationship, they could not talk with their spouses about their and their spouses' feelings.

- 'I wonder how bad my husband thinks of my image. I wasn't like this. I don't sleep with him, I can't ... I am sleeping separately so that I don't feel bad"(19. Participant).

- $\quad$ "My husband is with me and supports me. But I think he finds me ugly. I wonder if he still loves me. I do not know, I think that he does not find me as beautiful as before, so I feel sorry"(18. Participant).

- 'It didn't affect me. My husband also said that it didn't matter. He (shaking) loved, stroked my head. But while he was shaving my hair how did he feel? We must ask him. We have never talked about this. I did not ask why he was crying" (12.Participant).

\section{Trying not to worry children}

Some of the participants hid their disease, some hid chemotherapy, and some hid their feelings from their children. They acted in this way for two reasons. Firstly, they got more upset when their children commented on their appearance and felt upset. .Secondly, they wanted to protect their children emotionally as a mother.

- "I have two sons (crying). One is 4, one is ten years old. They (breathing deeply) especially my eldest son supported me and told me that it would be over. But the little one, he used to like playing with my hair. I felt so bad when he asked me where my hair was. I didn't know what to say, I couldn't breathe...I never wanted them to see me bald and ugly" (20. Participant).

- $\quad$ "I tried to hide it from my kids. One day my little girl noticed... I mean, I tried to comfort them. Then, I got used to it because I had nothing else to do" (8. Participant).

\section{Not wanting to meet people outside the family}

Since alopecia is a factor that makes cancer visible, the participants chose to move away from social circles. They did not want others to see them because they were worried about their opinions regarding their appearance. Some participants were worried about other people's questions and not knowing how to answer them. Those who were disturbed by the questions isolated themselves from society.

- 'I definitely don't want my students at school to see me like this. My friends, relatives... I don't want anyone to see me so helpless. The disease is okay, but as my hair and my eyebrow have fallen out, it feels like everyone knows my situation, it is very difficult (voice trembling). I can't bear those looks" (20. Participant).

- II'm ashamed of going out like this. I have not been meeting my friends. I couldn't enter those social circles....Although I had a wig, I did not...I only went for a walk in my environment. I went out in that way" (12. Participant). 


\section{Keeping Hope Alive}

The vast majority of the participants stated that they were very excited and happy when their hair started to grow. Their new hair was different in shape and color, which made them got excited.

- $\quad$ "Of course, I think I will be more beautiful and I will feel better. I mean, I will be more beautiful. I'll be like as I used to be. Nobody will look at me like this anymore. So I think I will feel better" (19. Participant).

\section{Facilitating the difficulties experienced \\ Having knowledge}

Participants who were informed about alopecia before chemotherapy accepted alopecia earlier and more easily. The process was not frightening because they knew about the situation they were going to experience. Those who were not informed had difficulty accepting it and shaved their hair as soon as alopecia started.

- "...We already knew the situation and saw people in our environment, we had family members with this disease... When I started CT, not nurses but friends and patients there helped me. They told me not to worry, and they had also lost their hair but grew again later. No problem..." (10. Participant).

\section{Believing that it has come from God}

Believing that what happened came from God and that this was a test was a factor that made it easier for participants to accept the situation. Some participants thought they should be patient and shouldn't complain because it was a test. Others thought that their disease or hair loss was their fate and volition of God, so they should accept it.

- " "Crying) Everything comes from God, there is nothing to do. God wanted it in this way'(13. Participant).

\section{Having support systems}

All of the participants stated that being supported by the family members is very important for them. The process was more bearable for the participants who received support from the people around them.

- "Of course the whole family is with me, everyone. We have gone through the same things with my sister before. Now it has happened to me. Everyone is with me and everyone is supporting me. My friends are supporting me" (18. Participant).

\section{Discussion}

Half of the participants perceived hair loss such a serious emotional problem that they defined it as "trauma". Some of the participants considered hair loss more important than breast loss, while others experienced negative emotions such as anxiety, panic, and regret with the onset of alopecia. In a study by Nizamli et al., one of the participants stated that "I used to think that breast loss was very important until I lost my hair...Losing hair was more destructive" [31]. The women stated that hair loss was more upsetting for them than breast loss. Even one of the participants did not want to receive chemotherapy because of hair loss, but finally, she had to receive it. The literature cites that the worst symptom experienced by women with breast cancer is sadness due to hair loss [13, 21, 32-35]. Browall et al. also reported that the alopecia was more difficult and painful than breast loss for patients (36), which is supported by other studies $[37,38]$.

Our study demonstrated that most participants knew that their hair would fall out, but they were not ready to encounter it. It was seen that as their treatment progressed, participants' negative feelings about alopecia decreased, and they started to accept the situation they were in and got used to being bald. Hesketh et al. defined a strategy consisting of stages to individualize alopecia treatment [39]. This strategy involves coping with the uncertainty and anxiety associated with hair loss in the process of waiting for the onset of alopecia, having the right expectation about the physical changes that will occur during the hair loss, and preparing the patient for psychological and social changes [40].

With the onset of hair loss, the participants experienced a change in their perception of appearance and identity and defined themselves as ugly and incomplete. As the participants had negative feelings about their appearance, they thought whatever they wore did not suit them. This is because the hair symbolizes femininity in many societies. Similarly, it has been reported in various studies that women experiencing alopecia also experience loss of femininity, sexuality, attractiveness, and self-confidence [13,41-45]. Abu-Helalah et al. evaluated the quality of life of women with breast cancer and determined that the lowest quality of life scores were obtained from sub-dimensions of body image and future anxiety.

The majority of the participants decided to have their hair cut or shaved it completely before the hair loss began not to see it falling. Trusson and Pilnick explained that women prefer to take control of hair loss by shaving their hair [41]. Women choose this method to prepare themselves and the people around them for the first encounter with alopecia and to reduce the trauma that may occur due to hair loss occurs after chemotherapy [42]. However, both this study and other studies have concluded that this not an easily acceptable method for women and does not support their body image [43].

It was found that women who covered their hair in the pre-disease period did not have difficulty in going out during this process, but continued to cover their hair not to be seen by their spouses and children when they were together at home. Literature reports that women use wigs, berets, bandanas, and scarves to hide their alopecia other than haircuts $[25,46]$. This result shows that women are uncomfortable with their appearance without hair and are trying to hide it.

The participants experienced changes in their family and social relationships as well as concerns about their appearance. Most of the participants were worried that their spouses did not like them, so they did not want to sleep in the same bed with their husbands. There are other studies with the same result [47-53]. The participants could not talk to their spouses about their appearance and feelings about their relationship. In addition, it was observed that the comments made by their children about their appearance affected their mood. Women with children were both trying to deal with negative emotions about themselves, and hiding their disease to protect their children. Related studies have shown that women feel the need to hide their appearance to prevent social isolation arising from the stigma that may occur in relation to their children carrying the disease gene as well [44,54].

Alopecia also negatively affected women's social relationships and they limited their relationships with people outside their families. In Rosman's study on the meaning of hair loss, alopecia is defined as a visible reminder of the disease and a noticeable condition by others [38]. In the qualitative study of Tusson and Pilnick, a participant decided not to use wigs and similar accessories at the beginning, but she realized that the people around him looked at her with pity, so she felt environmental pressure to cover her head [41].

Knowing that their hair will grow gives women hope for the future. In the qualitative study conducted by Kim and his friends, it was observed that the participants accepted the view that "If being bald represents being sick, new hair formation after alopecia represents the hope and renewal of life", and many of them felt happy by looking at their new hair [35].

In our study, it was concluded that having knowledge about alopecia, believing in fate and God, and being supported by people give strength to patients. Some of the women perceived the situation they experienced as a test. In parallel with this situation, it was seen that thanks to the defense mechanisms they had created with the thought of "We are pleased with everything coming from God", and accepted and adopted the alopecia process more easily than the others. Studies are suggesting that believing in God, accepting whatever comes from God and worshiping facilitates the adaptation process $[44,55,56]$. 
The spiritual support provided by family and friends made patients feel stronger. According to a patient, having an economic power enables to have some accessories to hide alopecia (wig, etc.). This view is also supported by another study [57].

The data of the study were collected from women through face-toface interviews. Using negative expressions about God in Muslim societies is generally not welcomed. Therefore, participants, who were all Muslims, may not have openly expressed their feelings (anger, fury, rebellion, etc.) not to contradict religious teachings. In addition, the majority of women wore headscarves before hair loss because of their religious values. For this reason, they may have accepted the situation more easily than those who wore headscarves for the first time. These elements constitute the limitations of the study.

Various studies in the literature show the negative impact of alopecia on women's body image. This study provides data about how alopecia is perceived in Turkish society. What a female cancer patients experienced due to hair loss was reported through the participants in their own words beyond numerical data. It is understood that it is not enough to tell women that their hair will fall out. In this cancer treatment journey, it is necessary to provide emotional support for women, to inform them about the options to contribute to the positive body image (wig, etc.) and how to reach these options. The study results are thought to shed light on the strategies that nurses and other team members will use to support the psychological and social health of breast cancer patients with alopecia.

Conflict of interests: The authors declare no conflict of interest.

\section{References}

1. Estimated Cancer Incidence, Mortality and Prevalence Worldwide. (2012). Electronic resources [online]. Available from: http://globocan.iarc.fr/Default.aspx. [Erişim 20 Şubat 2015].

2. https://www.uicc.org/news/globocan-2020-new-global-cancerdata. Accessed 10 April 2021.

3. Sağlık İstatistikleri Yıllığı. (2017). T.C. Sağlık Bakanlığı Yayın No:1106. Kuban Matbaacılık ve Yayıncılık. Ankara, 40-41.

4. Sağlık Bakanlığı. (2019). Türkiye Halk Sağlığı Kurumu. Erişim: 18 Ocak 2019. Meme Kanseri Tarama Programı Ulusal Standartlart. https://hsgm.saglik.gov.tr/tr/kanser-taramalari.. [Erişim 06 Nisan 2015].

5. Çalışkan, Z. (2007). Erken evre meme kanserli kadınlarda ameliyat tercihleri ve tercihleri etkileyen değişkenler. Yüksek lisans tezi, Ege Üniversitesi Sağlık Bilimleri Enstitüsü, İzmir.

6. Yıldırım, M. (2008). Meme cerrahisi geçirmiş kadınların ruhsal durumları ve algıladıkları sosyal destek düzeyleri ile ilgili bir çalışma. Yüksek lisans tezi, Haliç Üniversitesi Sağlık Bilimleri Enstitüsü, İstanbul.

7. Garip, M. (2008). Meme kanseri nedeniyle opere olan hastalarda meme koruyucu cerrahi ya da radikal mastektomi kararını etkileyen faktörler ve cerrahi türünün hasta üzerindeki etkileri. Uzmanlık tezi, Sağlık Bakanlığı Dr. Lütfi Kırdar Kartal Eğitim ve Araştırma Hastanesi, İstanbul.

8. Gümüş, A. B. (2006). Meme kanserinde psiko-soyal sorunlar ve destekleyici girişimler. Meme Să̆lı̆̆ Dergisi 2: 108-14.

9. Güntekin, N. O. (2009). Kadınların meme kanserine ilişkin algıları: bir fokus grup çalışması. Yüksek lisans tezi, Ege Üniversitesi Sağlık Bilimleri Enstitüsü, İzmir.

10. Kaymakçı, Ş. (2014). Meme hastalıkları. Dahili ve Cerrahi Hastalıklarda Bakım (Ed: Karadakovan A, Eti Aslan F). Ankara, 919-45.

11. Baykara, O. (2016). Kanser tedavisinde güncel yaklaşımlar. Balıkesir Sağlık Bilimleri Dergisi 5:154-165.
12. Karayurt, Ö. (2014). Meme kanseri. Onkoloji Hemşireliği. (Ed: Can G). Istanbul, 619-657.

13. Arıkan Dönmez, A. (2012). Meme kanseri olan hastalarda scalp cooling (saçlı deriyi soğutma) yönteminin kemoterapiye bağl1 saç kaybı üzerine etkisi. Yüksek lisans tezi, Cumhuriyet Üniversitesi Sağlık Bilimleri Enstitüsü, Sivas.

14. Gupta, S., Khatoon, R. (2015). Hair loss-an analys and updated treatment. Journal of Dental and Medical Sciences 14:77-81.

15. Oğuz, O. (2014). Alopesi areata. Türkderm-Deri Hastalıkları ve Frengi Arşivi Dergisi 48: 4-40.

16. Batchelor, D. (2001). Hair and cancer chemotherapy: consequences and nursing care a literature study. European Journal of Cancer Care 10: 147-163.

17. Choin, S. Y., Champion, R. W., Rashid, R. M. (2012). Chemotherapy-induced alopecia. J Am Acad Dermatol 67:3845.

18. Trüeb, R. M. (2009). Chemotherapy-induced alopecia. Semin Cutan Med and Surg 28: 11-14.

19. Hurk van den, C. J. G., Mols, F., Vingerhoets, M. J. J., A, Breed, P. M. W. (2009). Impact of alopecia and scalp cooling on the well-being of breast cancer patients. Psycho-Oncology 19:701-719.

20. Özgül, N., Erten, Ö., Düzgüner, S., Turan, T., Kög, İ., Boran, N., Balta, İ., Köse, M. F., (2011). Paklitaksen/platin kombinasyonu ve alopesi. J Turk Soc Obstet Gynecol 9: 94-8.

21. Choi, E. K., Kim, I. R., Chang, O., Kang, D., Nam, S. J., Lee, J. E., Lee, S. E. (2014). Impact of chemotherapy-induced alopecia distress on body image, psychosocial well-being, and depression in breast cancer patients. Psycho-Oncology 23: 1103-1110.

22. Villasante, A. C., Herskovitz, İ., Mauro, L. M., Jimmenez, J. J. (2014). Chemotherapy-induced alopesia. J Clin Investigat Dermatol 4:281-284.

23. Rose, H. (2011). Chemothrapy-induced alopecia: advice and support for hair loss. British Journal of Nursing 20:1-10.

24. Vleut, R. E., Van Poppel, J. E. A. M, Dercksen, M. W., Peerbooms, M., Houterman, S., Breed, W. P. M. (2013). Hair mass indeks obtained by crossection trichometry: an objective and clinically useful parameter to quantify hair in chemotherapyinduced alopesia. Support care cancer 21:1807-14.

25. Hindistan, S., Çilingir, D., Nural, N., Akkaş Gürsoy, A. (2012). Hematolojik kanserli hataların kemoterapiye bağlı yaşadıkları semptomlara yönelik uygulamaları. Gümüşhane Üniversitesi Sağlık Bilimleri Dergisi, 1: 153-164.

26. Bahçetepe, N., Kutlybay, Z., Engin, B., Tüzün, Y. (2013). Kemoterapi ajanlarının kutan etkileri. Dermatoz 4: 69-76.

27. Can, G. (2005). Antineoplastik ilaçların yan etkileri ve hemşirelik yaklaşımları. Hemşirelikte Eğitim ve Araştırma Dergisi 2: 8-15.

28. Karabulutlu, Ö. (2009). Kemoterapi alan hastalarda semptom yönetimi ve yaşam kalitesinin sürdürülmesi. İstanbul üniversitesi Florence Nightingale Hemşirelik Dergisi 17:218-225.

29. Çekmez, E., Yıldız, C., Bütüner, S. Ö. (2012). Fenomenografik araştırma yöntemi. Necatibey Eğitim Fakültesi Elektronik Fen ve Matematik Ĕ̌itimi Dergisi 6:71-102.

30. Yıldırım, A., Şimşek, H. (2006). Sosyal Bilimlerde Nitel Araştırma Yöntemleri. Altıncı baskı. Seçkin Yayıncılık, Ankara; 253-275

31. Nizamli, F., Anoosheh, M., Mohammadi, E. (2011). Nursing and Health Sciences 13: 481-487.

32. Reich, M., Lesur, A., Perdrizet-Chevallier, C. (2008). Depression, quality of life and breast cancer: a review of the literatüre. Breast Cancer Res Treat 110:9-17. 
33. Abu-Helalah, M., Al-Hanaqta, M., Alshraid, H., Abdulbgi, N., Hijazeen. (2014). Quality of life and psychological well-being of breast cancer survivors in Jordan. Asian Pasific Journal of Cancer Prevention 15:89-95.

34. Niklasson, A., Paty, J., Ryde, A. (2017). Talking about breast cancer: which symptoms and treatment side effects are important to patients with advanced disease?. Patient 10 (6): 719-727.

35. Kim, I. R., Cho, J., Choi, E. K., Kwon, I. G., Sung, Y. H., Nam, S. J., Yang, J. H. (2012). Perception, attitudes, preparedness and experience of chemotherapy-induced alopecia among breast cancer patients: a qualitative study. Asian Pasific Journal of Cancer Prevention 13:10086-10095.

36. Browall, M., Johansson, F. G., Danielson, E. (2006). Postmeaopausal women with breast cancer their experience of chemotherapy treatment period. Cancer Nursing 29:7-12.

37. Lemieux, J., Maunsell, E., Provencher, L. (2008). Chemotherapy-induced alopecia and effects on quality of life among women with breast cancer: a literature review. PsychoOncology 17:317-328.

38. Dubey, K., Gupta, U., Jain, S. (2015). A survey on breast cancer scenario and prediction strategy. Proceedings of the 3rd International Conference on Frontiers of Intelligent Computing: Theory and Applications (Ed. Chandra SS, Biswal BN, Udgata SK, Mandal J.K.). Switzerland 367-365.

39. Chen, S. Q., Liu, J. E., Li, Z., Su, Y. L. (2017). The process of accepting breast cancer among Chinese women: A grounded theory study. Europen Journal of Oncology Nursing 28: 77-85.

40. Hesketh, P. J., Batchelor, D., Golant, M., Lyman, G. H., Rhodes, N., Yardley, D. (2004). Chemotherapy-induced alopecia: Psychosocial impact and therapeutic approaches. Supportive Care in Cancer, 12:543-549.

41. Trusson, D., Pilnick, A. (2016). The role of hair loss in cancer identity. Cancer Nursing 39: 25-38.

42. Frith, H., Harcout, D., Fussel, A. (2007). Anticipating an altered appearance: women undergoing chemotherapy treatment for breast cancer. Europen Journal of Nursing 11:385-391.

43. Zannini, L., Verderame, F., Cucchiara, G., Zinna, B., Alba, A., Ferrara, M. (2012). My wig has been my journey's companion: perceived effects of an aesthetic care programme for İtalian women suffering from chemotherapy-induced alopecia. Europen Journal of Cancer Care 5: 1-11.

44. Dsouza, M. S., Vyas, N., Narayanan, P., Parsekar, S. S., Gore, M., Sharan, K. (2017). A qualitative study on experience and needs of breast cancer in Katarka. Clinical Epidemiology and Global Health 6:197.

45. Schmidt, S., Fischer, T. W., Chren, M. M., Streauss, B. M., Elsner, P. (2001). Strategies of coping and quality of life in women with alopecia. British Journal of Dermatology 144: 1038-1043.

46. Ateş, S., Olgun, N. (2014). Kemoterapiye bağl1 alopesi ve yaşam kalitesi. Hacettepe Üniversitesi Hemşirelik Fakültesi Dergisi 15:67-80.

47. Erol, O., Can, G., Aydiner, A. (2012). Effects of alopecia on body image and quality of life Turkish cancer women with or without headscarf. Supportive Care in Cancer 20:2349-2356.

48. Jassim, G. A., Whitford, D. (2013). Quality of life of Bahraini women with breast cancer: a cross sectional study. BMC Cancer 13:212 2-14

49. Chung, C. W., Hwang, E. K. (2012). Couples' experiences of breat cancer in Korea. Cancer Nursing 35( 3): 211-220.

50. Nasiri, A., Taleghani, F., Iraipour, A. (2012). Men's sexual 1ssues after breast cancer in their wives. CanserNursing 35:236-244.
51. Fang, S., Chang, H., Shu, B. (2015). The moderating effect of perceived partner empathy on body image and depression among breast cancer survivors. Psycho-Oncology 24: 18151822 .

52. Jankowska, M. (2013). Sexual functioning in young women in the context of breast cancer treatment. Oncology and Radiotherapy 18:193-200.

53. Gürsoy, A., Koçan, S., Aktuğ, C. (2017). Nothing is more important than my partner's health: Turkish men's perspectives on partner's apperance after mastectomy and alopecia Oncology Nursing 29: 23-30.

54. Can, G. (2007). Alopesi. Onkoloji Hemşireliğinde Kanıta Dayalı Semptom Yönetimi. (Ed. Can G). Ístanbul, 133-141.

55. Doumit, A. A. M., Huijer, H. A., Kelley, J.H., Saghir, N. E., Nassar, N. (2010). Coping with breast cancer a phenomenological study. Cancer Nursing 33(2): 33-35.

56. Daştan, B. N., Buzlu, S. (2007). Meme kanseri hastalarında maneviyatın etkileri ve manevi bakım. Maltepe Üniversitesi Hemşirelik Bakım ve Bilim Sanatı Dergisi 3(1): 73-78.

57. Donovan, J. C., Shapiro, P., Zupan, M., Pierre-Lois, M., Hordinsky, M. (2012). A review of scalp camouflaging agents and prostheses for individuals with hair loss. Dermatol Online Journal 18:185-219. 